\title{
Model of Grid-Connected PV System in Sarawak, Malaysia Rural Area
}

\author{
Yanuar Z. Arief \\ Dept. of Electrical and Electronic Eng. \\ Universiti Malaysia Sarawak, Malaysia \\ Dept. of Electrical Engineering \\ Jakarta Global University, Indonesia \\ ayzulardiansyah@unimas.my
}

\author{
Sebastian Sulau Anak Sa-Or \\ Dept. of Electrical and Electronic Eng. \\ Universiti Malaysia Sarawak \\ Kota Samarahan, Sarawak, Malaysia \\ 59161@siswa.unimas.my
}

\author{
Naemah Mubarakah \\ Dept. of Electrical Engineering \\ Universitas Sumatera Utara (USU) \\ Medan, Indonesia \\ naemah@usu.ac.id
}

\author{
Mohd Hafiez Izzwan Saad \\ Dept. of Electrical and Electronic Eng. \\ Universiti Malaysia Sarawak, Malaysia \\ smhizzwan@unimas.my
}

\author{
Hamzah Eteruddin \\ Department of Electrical Engineering \\ Universitas Lancang Kuning, Indonesia \\ hamzah@unilak.ac.id
}

\begin{abstract}
Sarawak is largest states in Malaysia and is gifted with lush forest and hilly terrains. However, due to this topography, Sarawak Energy Berhad (SEB) has difficulty to supply a reliable source of electricity to all areas of Sarawak. There are even areas with grid connection that occasionally suffer from power outage. Solar energy can be seen as a solution to the problem of supplying reliable power. However, installing and operating a PV system to generate power will require some insight on the location and the technical information of the PV system. Therefore, this paper aims to collect and analyze the resource data of the locations in Sarawak as well as the possible characteristics of a grid-connected PV system. The project starts with the possible locations of the PV system. The locations include area throughout Sarawak such as Sri Aman, Kapit, Limbang, Lundu, Sebuyau, Tatau and Lawas, respectively. The resource data of the area such as the average annual irradiance and the average annual ambient temperature is collected through HOMER software. The components used to test the characteristics of the PV system are CanadianSolar KuBlack C32K 300MS solar panel, Mitsubishi Electric PV-MLU250HC solar panel, Canadian Solar Single Phase String Inverter CSI2KTL1P-GI-FL and Mitsubishi Electric Photovoltaic Inverter PV$S 2600$, respectively. Then, the components will interchange into a combination of one PV module and one inverter to make four different sets of $P V$ system. The result of the project revealed that the area of Limbang and Lawas is the most suitable for a Gridconnected PV system because the two areas have high irradiance and low ambient temperature. The most suitable combination of components is the Mitsubishi Electric PV-MLU250HC solar panel and CanadianSolar Single Phase String Inverter CSI-2KTL1P-GIFL. This combination component has the least loss which means the PV system is efficient.
\end{abstract}

Keywords-grid-connected PV system, ambient temperature, sizing of inverters, balance of system (BOS), PV array configuration.

\section{INTRODUCTION}

Sarawak is one of the states in Malaysia which located to the north of Borneo island and as the largest state in Malaysia with a geographical area of $124,449.51 \mathrm{~km}^{2}$ which is approximately 37 percent of Malaysia area [1]. The electrical power supplied in Sarawak is performed by Sarawak Energy Berhad (SEB). As Sarawak is made up of hilly areas, mountains, and many remote, inaccessible area, it is a challenge for SEB to supply the entire Sarawak population as there are people living in these harsh and difficult to reach places. However, some of the village do have electrical power supplied via diesel generator (genset), but these genset does not supply a reliable $24 / 7$ electrical power supply as well as using diesel as fuel, a fuel that requires a long commute to obtain.

The community in these areas are generally small. There are approximately more than $75 \%$ of these villages has fewer than 50 households and 1919 villages totaling up to 41,004 households are not supplied with continuous electricity. Moreover, 18,038 households are taken into consideration for grid connection but still require access and another 12,452 households are to be deemed too remote, hence not grid connectable [1].

Therefore, turning to renewable energy to provide a reliable electricity to these Sarawak rural areas are significant to both improve livelihood of these areas and meet the evergrowing power demand in Sarawak. Thus, this paper will study on modelling of an operating grid-connected PV system in the areas of Sarawak. Then, to analyse the factors such as irradiance, location, ambient temperature in the different areas in Sarawak as well as the PV module parameters and Inverter parameters that will affect the characteristics of the PV system. Finally, to compare and select the characteristics of the PV system which are applicable in the different areas in Sarawak.

\section{Methodology}

\section{A. PV System Design}

PV system can be either a standalone off-grid PV system or a grid-connected PV system. In both of these cases, there are similarities as well as differences in the component used in the system. However, the aspect that are taken into account are 